\title{
Open access publishing: Hypocrisy and confusion in geography
}

\section{Jenny Pickerill}

Department of Geography, Leicester University, University Road, Leicester, LE1 7 RH, England, +44(0)116 252 3836, j.pickerill@leicester.ac.uk

\section{[Final submission draft: $29^{\text {th }}$ June 2007]}

Debates about the possibilities and importance of open access publishing in academia are reaching a crucial stage. British universities are implementing 'author archiving', electronically storing their staff's outputs for online public access. At the same time, an increasing number of academics are calling for an overhaul of journal publishing processes - urging us to sign a petition to the European Commission in support of open access (EC Petition, 2007). Journal publishers are fighting a rearguard action in response. This ranges from making some of their content freely available, to creating complicated licence forms allowing authors to only post articles online several months (in some cases years) after publication; the chief concern of publishers is the potentially dramatic loss of revenue (Shepherd, 2007).

The result for academics is a messy and confusing situation where even fine attention to the small print of such licences offers little clarity. Whether we are correctly abiding by these licences or not, there needs to be a more assertive discussion within academic geography about our outputs. Many geographers have critically engaged with our publishing practices, encouraging academics to write in more accessible styles and in non-academic locations (Castree, 2006; Smith, 2000; Mitchell, 2006). Condemnation of the negative consequences of the Research Assessment Exercise (RAE) on how we publish abounds, as does criticism of the Anglo-American hegemony in our conferences and publishing (Minca, 2003). Moreover, the recent campaign to boycott Elsevier publications (including Political Geography, Geoforum, and Applied Geography) due to their support for arms trading has highlighted how "academic practices are increasingly enmeshed with capitalist social relations through their links with, and dependency on, multinational publishing companies" (Chatterton and Featherstone, 2006, 5). This move to be more critically aware of the commercialisation not just of our institutions, but also our outputs, is necessary and welcome. However, if as critical geographers we are suggesting that "the ethics of the companies we do this work for should broadly reflect the ethics and values of those who do this work" (Chatterton and Featherstone, 2006, 5), then we need to go far beyond objecting to one publisher's financial approach, and as Kitchin (2007) suggests, more broadly examine our complicity in the military-industrial complex not just in where we publish but in investments made in our name (such as pension funds) (Macdonald, 2007).

The hypocrisy of not making all our academic writings freely available is most acute for so-called radical and critical geographers. Not only do many of us advocate reaching beyond academic boundaries in our actions, teaching and writings, 
assertively criticising any division between the 'real world' and academia, but many of us engage with those who advocate the necessity of a 'creative commons', challenge notions of copyright, or build open publishing alternatives, such as Indymedia (Pickerill, 2007). Geographers have progressively sought alternatives to current publishing systems. ACME, established in 2002, was founded in recognition of the need to democratise knowledge production and to "challenge the political economy of academic journal publishing. Our underlying purpose in creating an international ejournal for critical geographies is to make critical work accessible for free" (Moss et al., 2002, 2) while still retaining a peer review process. Associated with ACME is the Praxis (e)Press, an open access e-book publishing house, through which geographers have published an edited collection freely available for download online (Fuller and Kitchin, 2004).

However, there remains a bias (even by critical geographers) in favour of publishing in established hardcopy journals with better RAE credibility. Such journals' approaches to open access are extremely limited. Antipode's Exclusive Licence Form enables authors to post "an electronic version of the Article on your own personal website, on your employer's website/repository and on free public servers in your subject area". However, this only applies to the original version. The final copy may only be posted online 24 months after publication and the authors are not permitted to post the PDF version. Other geography journals, such as Progress in Human Geography, allow on-line posting after 12 months, but again not using the PDF version. This delay, in addition to the long print time of journals, has meant for example, rather ironically, that an article I wrote about open publishing in 2003 will not be freely available in final form until 2009 (Pickerill, 2007).

Part of the problem is confusion about what open access actually means. In 2004, to great fanfare, Elsevier announced they were allowing open access to their journals. In practice they simply allowed authors to re-post their articles on their own websites. To those advocating open access, such as Cockerill of BioMed Central, an open access publisher, Elsevier's move was "so partial compared with open access [that] this kind of archiving is in many ways useless to the majority of scientists, mainly because no one will know the copies exist at all or where to find them" (quoted in Wray, 2004).

At the very least geographers should sign the EC petition (www.ec-petition.eu) that calls for a guarantee of 'public access to publicly-funded research results shortly after publication'. But beyond this we need a more thorough discussion of how we publish our work; what form of open access do we want and how could we ensure that we maintain our peer-review process (and the editing and work this entails) while making sure our work is freely available to all?

It is not enough to advocate that we should simply write more - balancing our academic output with work in more non-academic locations. It is time consuming, repetitive and unnecessary. Instead we need to think critically about how to support open access without undermining the importance of the peer-review process. This has been done by a number of journals using the 'author-pays' approach whereby academics pay to have their work published but it is then freely available to all. In addition, such work is advertised and logged into academic databases. University archives and our own websites are limited by obscurity and a lack of interoperability standards between them. Our work needs not only to be online but easily searchable. But who would want to pay (and where would the money come from?) to submit an 
article and what further power hierarchies might this create? Some suggest that institutions or funding bodies would likely cover the cost. However, such an approach raises many questions about whose work would then be submitted and whose might not. ACME is largely based on volunteer effort and tries to reduce editors' workload by spreading the work of editing across its board and requiring authors do more of the proof work than in paper journal publishing. An alternative approach is to urge journals to reduce the embargo time they currently attach to articles and push them to release the material freely and more quickly. Publishers argue this will reduce their subscriptions and potentially result in bankruptcy.

As geographers concerned with power, justice and resistance we need to be reflective of our positions within this debate and of the ways our current actions fail to embrace the possibilities of open access. We also need to be creative in our solutions. Beyond academia the concept of 'open publishing' has been thoroughly explored and tested. Indymedia developed a form of alternative news-making that encouraged any user to contribute content (be it text, graphics, audio or video) and discussion with very little moderation. We might not want to be as radical in our approach as Indymedia, however, in many ways geography academics are behind the times in making use of the possibilities of the internet for dissemination. Despite journals such as ACME and online projects such as Madge et al. (2006) the emphasis (and recognition) remains on submissions to hardcopy journals.

Posting our publications on personal websites is a start, but a poor one. They are hard to find, search, and are often created to boost reputation or citation (I am as guilty of this as anyone else). Thus we need to critically examine our motives and focus on those actions that will enable our work to reach the biggest audience. There are five ways we can begin to do this now.

First, we need to better inform ourselves about the political economy of publishing in which we are the key producers of knowledge. Second, ensure that our websites contain downloadable copies of our original manuscripts and support our University-specific repositories. Crucially, in addition to this use Creative Commons licenses which use meta data thus increasing the efficiency of searches, for example via Google scholar. Third, we should publish at least some of our outputs regularly in open access journals, if for no other reason that to reduce our own hypocrisy. Fourth, challenge journals to become open access. We need to make demands of publishers or else they will continue to view us as a passive resource. We need to stand together in making these demands to make it clear to publishers that without academics they have no business. Finally, we should practice disobedience by placing more of our material online. We need to do this as a clear statement of our long term intensions and to signal to publishers and society more broadly that open access academic publishing is valuable, important and necessary. In summary, any approach to this issue has some form of cost, but if we really are radical geographers who read a 'radical journal of geography' we should at the very least be having an urgent and informed debate about open access publishing.

\section{$\underline{\text { ACKNOWLEDGEMENTS }}$}

Thanks to Mathias Klang who was especially constructive in suggestions of how to embrace open access publishing.

\section{REFERENCES}

Castree, N (2006) ‘Geography’s New Public Intellectuals?’ Antipode, 38, 2: 396-412. 
Chatterton, P and Featherstone, D (2006) 'Intervention: Elsevier, critical geography and the arms trade' Political Geography, 26, 3-7

EC Petition (2007) 'Petition for guaranteed public access to publicly-funded research results' www.ec-petition.eu. Accessed $16^{\text {th }}$ February

Fuller, D and Kitchin, R (2004) Radical Theory/ Critical Praxis: Making a Difference Beyond the Academy? Praxis (e)Press), www.praxisepress.org/rtcp/contents.html

Kitchin, R (2007) Intervention: Elsevier, the arms trade, and forms of protest - A response to Chatterton and Featherstone, Political Geography, 26, 499-503.

Macdonald, I (2007) 'At British universities, a nascent divestment movement' International Herald Tribune, $22^{\text {nd }}$ June, http://www.iht.com/articles/2007/06/21/business/mcolumn23.php

Madge, C, Hooley, T, Meek, J, O’Connor, H, Shaw, R and Wellens, J (2006) Exploring Online Research Methods in a Virtual Training Environment, www.geog.le.ac.uk/orm Accessed $16^{\text {th }}$ February

Minca, C (2003) 'Critical peripheries' Environment and Planning D: Society and Space, 21, 30-38

Mitchell, K (2006) 'Writing from the Left Field' Antipode, 38, 2, 205-212.

Moss, P, Berg, L, D and Desbiens, C (2002) 'The Political Economy of Publishing in Geography' ACME, 1, 1, 1-7.

Pickerill, J (2007, forthcoming) “Autonomy on-line': Indymedia and practices of alter-globalisation' Environment and Planning A, 39.

Shepherd, J (2007) 'Open season for researchers' The Guardian, $13^{\text {th }}$ February, 10.

Smith, N (2000) 'Who rules this sausage factory?' Antipode, 32, 3, 330-339

Wray, R (2004) 'Reed allow academics free web access' The Guardian, $3^{\text {rd }}$ June. 